\title{
A Short Review on Recent Advances of Hydrogel-Based Adsorbents for Heavy Metal Ions
}

\author{
Suguna Perumal $1, *,+(\mathbb{D}$, Raji Atchudan $1, *,+(\mathbb{D}$, Thomas Nesakumar Jebakumar Immanuel Edison $1,+(\mathbb{D}$, \\ Rajendran Suresh Babu ${ }^{2,+}{ }^{-}$, Petchimuthu Karpagavinayagam ${ }^{3,+}$ and Chinnapiyan Vedhi ${ }^{3,+}$ \\ 1 School of Chemical Engineering, Yeungnam University, Gyeongsan 38541, Korea; jebakumar84@yu.ac.kr \\ 2 Laboratory of Experimental and Applied Physics, Centro Federal de Educação Tecnológica, \\ Celso Suckow da Fonseca (CEFET/RJ), Av. Maracanã 229, Rio de Janeiro 20271-110, Brazil; \\ ryesbabu@gmail.com \\ 3 Department of Chemistry, V.O. Chidambaram College, Thoothukudi 628008, Tamil Nadu, India; \\ karpagavinayagam2009@gmail.com (P.K.); cvedhi23@gmail.com (C.V.) \\ * Correspondence: suguna.perumal@gmail.com (S.P.); atchudanr@yu.ac.kr (R.A.) \\ + Authors contributed equally to this work.
}

\section{check for} updates

Citation: Perumal, S.; Atchudan, R.; Edison, T.N.J.I.; Babu, R.S.;

Karpagavinayagam, P.; Vedhi, C. A Short Review on Recent Advances of Hydrogel-Based Adsorbents for Heavy Metal Ions. Metals 2021, 11, 864. https://doi.org/10.3390/ met11060864

Academic Editors: Man-Seung Lee,

Felix A. Lopez and Anna

H. Kaksonen

Received: 4 May 2021

Accepted: 22 May 2021

Published: 25 May 2021

Publisher's Note: MDPI stays neutral with regard to jurisdictional claims in published maps and institutional affiliations.

Copyright: (c) 2021 by the authors. Licensee MDPI, Basel, Switzerland. This article is an open access article distributed under the terms and conditions of the Creative Commons Attribution (CC BY) license (https:// creativecommons.org/licenses/by/ $4.0 /)$.

\begin{abstract}
The growth of industry fulfills our necessity and promotes economic development. However, pollutants from such industries pollute water bodies which pose a high risk for living organisms. Thus, researchers have been urged to develop an efficient method to remove toxic heavy metal ions from water bodies. The adsorption method shows promising results for the removal of heavy metal ions and is easy to operate on a large scale, thus can be applied to practical applications. Numerous adsorbents were developed and reported, among them hydrogels, which attract great attention because of the reusability, ease of preparation, and handling. Hydrogels are generally prepared by the cross-linking of polymers that result in a three-dimensional structure, showing high porosity and high functionality. They are hydrophilic in nature because of the functional groups, and are non-toxic. Thus, this review provides various methods of hydrogel adsorbents preparation and summarizes recent progress in the use of hydrogel adsorbents for the removal of heavy metal ions. Further, the mechanism involved in the removal of heavy metal ions is briefly discussed. The most recent studies about the adsorption method for the treatment of heavy metal ions contaminated water are presented.
\end{abstract}

Keywords: heavy metal ions; adsorption method; adsorbents; polymer-based hydrogels; removal efficiency; adsorption capacity

\section{Introduction}

Essential ions participate in a various biochemical process that helps to maintain biological activities in a living organism. Essential elements such as nitrogen, oxygen, hydrogen, sulfur, calcium, potassium, sodium, magnesium, phosphorus, chloride, and essential trace elements like fluorine, iodine, iron (Fe), lead (Pb), manganese (Mn), copper $(\mathrm{Cu})$, chromium $(\mathrm{Cr})$, molybdenum (Mo), selenium (Se), cobalt (Co), zinc (Zn), and vanadium $(\mathrm{V})$ are necessary for living organisms to balance life functions [1-3]. Fluorine prevents dental cavities [4], calcium is beneficial for bone health [5], chromium helps potentiate the actions of insulin [6], iron is necessary for oxygen transport [7], copper and zinc play a vital role in metabolism [8], and iodine is advantageous in the regulation of thyroid hormones [2]. However, deficiency or low levels of these essential elements in living organisms leads to damage, ill effects, and alters functions of the body [9]. Furthermore, the presence of an excessive amount of essential metal ions, toxic metal ions, non-essential metal ions [10], or metalloids in unwanted places is considered a contaminant that affects humans and the environment. Contaminants or toxic metal ions include $\mathrm{Zn}, \mathrm{Mn}, \mathrm{Cu}, \mathrm{Pb}$, uranium (U), silver (Ag), strontium (Sr), tungsten (W), cesium (Cs), cadmium (Cd), nickel 
$(\mathrm{Ni}), \mathrm{Mo}$, arsenic (As), Cr, mercury (Hg), V, Se, aluminum (Al), and Co [1,11]. Lack of essential elements affects the uptake of non-essential elements, e.g., the presence of a high level of $\mathrm{Zn}$ will result in $\mathrm{Cu}$ deficiency [12]. A vitamin $\mathrm{D}$ deficiency will affect the deposition of calcium in bones. Fe deficiency will increase the uptake of $C d$, which interferes with the metabolism of $\mathrm{Zn}$ essential metal ions [13]. Thus, a metal speciation analysis helps to identify the safe and dangerous limits of heavy metal ions in water systems. Generally, metal speciation is done using measurements such as atomic absorption spectrometry (AAS), gas chromatography coupled with high-performance liquid chromatography, electrochemical methods, and optical measurements [14-17]. AAS has been used for the speciation of As (III) and As(V) [18-20]. Other than these methods, recently, surface-enhanced Raman spectroscopy has been used to analyze the $\mathrm{Cr}(\mathrm{Vi})$ and $\mathrm{Cr}(\mathrm{III})$ ions in water [21].

The major sources of heavy metal ions are pesticides, fungicides, refineries, fertilizers, mining, smoking, nuclear fission plants, chemical industry, paint, electroplating, welding, automobiles, batteries, and so on [22]. Heavy metal ions contamination results in damage to aquatic systems and organs in humans such as lungs, kidneys, central nervous system, nose, skin, gastrointestinal tract, and brain [3,10,23-28]. Figure 1 depicts the human organs affected by the excess of heavy metal ions that are released from various sources.

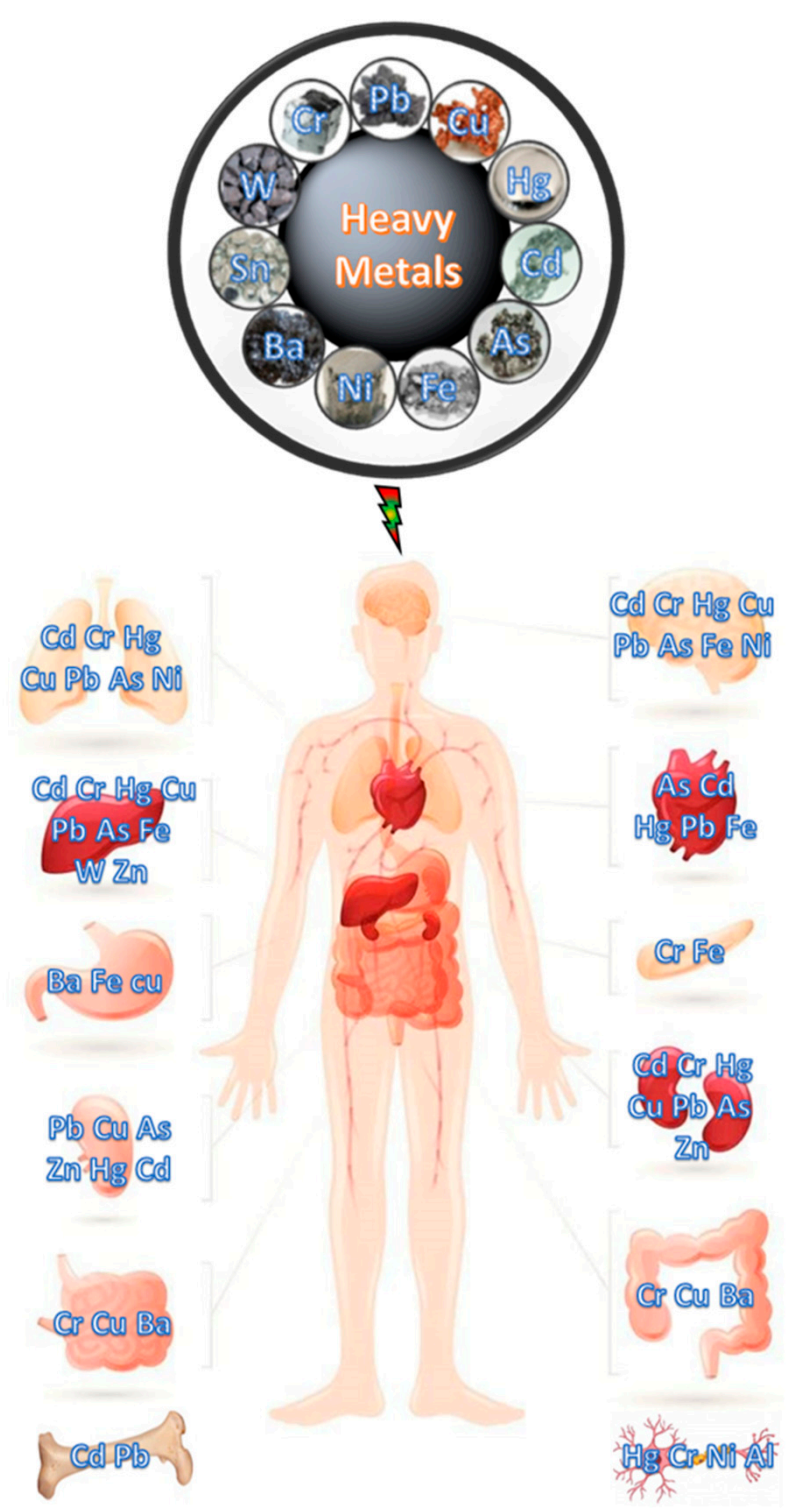

Figure 1. Illustration of human organs affected by the excess of heavy metal. 
Many efforts have been put forward to remove the heavy metal ions from polluted water. Figure 2 illustrates the different methods to purify the polluted water such as chemical precipitation [29-31], coagulation and flocculation [32-34], membrane filtration [35-37], ion flotation [38-40], ion-exchange [41-44], electrochemical treatment [45,46], and adsorption [47-51].

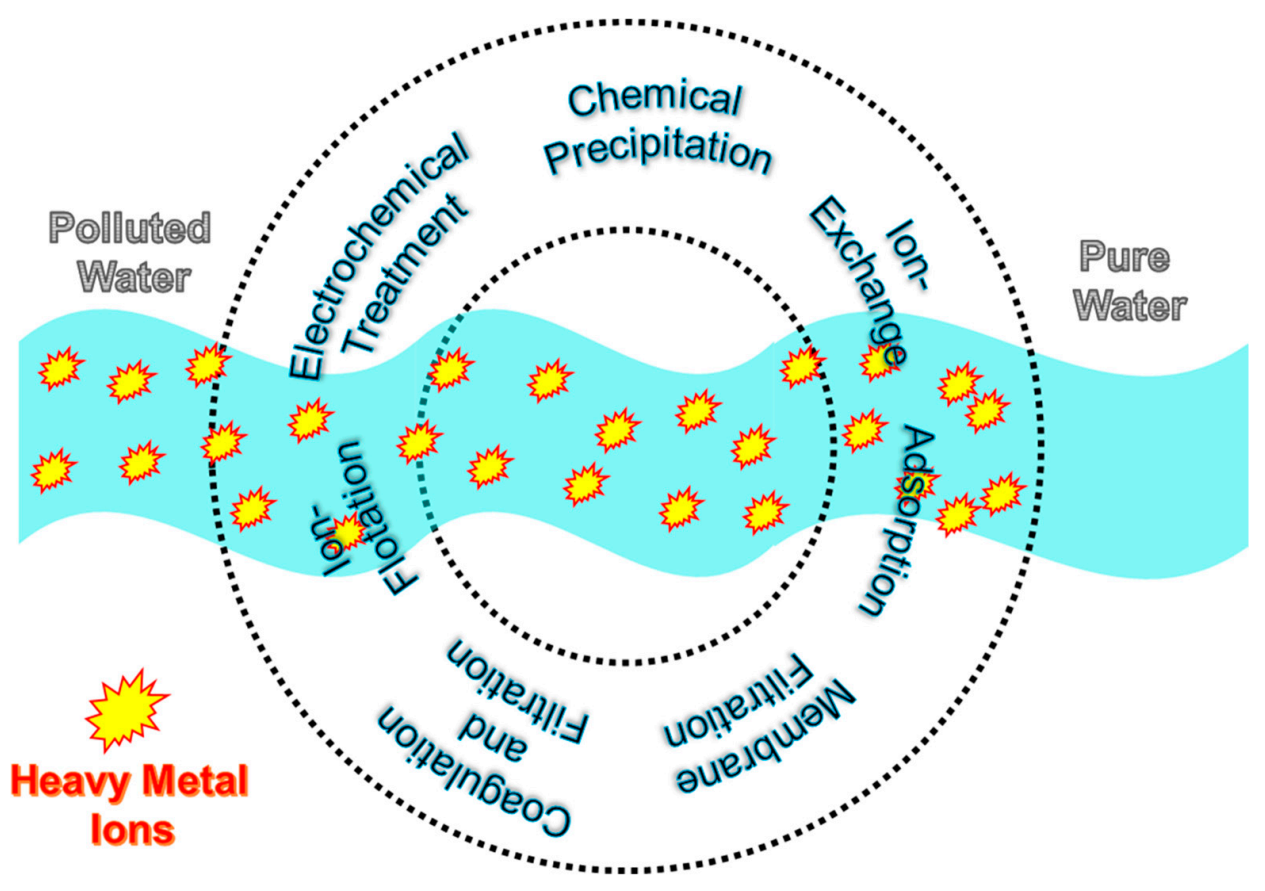

Figure 2. Different methods used to purify heavy metal ions in polluted water.

\section{Chemical Precipitation}

Chemical precipitation is a method where heavy metal ions are separated from the contaminated water as sediments [29-31]. The precipitates are formed by the complexes of heavy metal ions with precipitation agents or coagulants which can be separated by filtration or centrifugation. The parameter which needs to be adjusted in the chemical precipitation method is $\mathrm{pH}$. This method has advantages and disadvantages. The advantage of this method is that it is inexpensive. However, disposal of the large amount of sludge produced during purification requires additional costs.

\section{Coagulation and Flocculation}

The heavy metal ions are removed by adsorption, complexation, and co-precipitation from the water system [32-34]. It is a simple, integrated physicochemical process, and an inexpensive method. Complete removal of heavy metal ions is difficult, requires chemicals, and large amounts of sludge are produced during separation.

\section{Membrane Filtration}

Membrane filtration is a non-destructive separation method using a semipermeable barrier. Reverse osmosis is involved in this separation method [35-37]. This method requires very simple equipment, can be conducted in a small space, is effective at high concentrations, and no chemical is required. However, investment and maintenance are expensive, the design of the membrane filtration system can differ significantly, and selection of the membrane is required.

\section{Ion-Flotation}

Ion flotation involves the removal of heavy metal ions by the complex formation between surfactant (with opposite charge) and target ions [38-40]. Bypassing gas bubbles in the wastewater, heavy metal ions complexes will float on the surface and thus contaminants 
are purified. The disadvantage of this method is that the initial investment, instrument maintenance, and operation cost are expensive.

\section{Ion-Exchange}

This is a physical separation process in which organic resins, inorganic three-dimensional matrix, and new-generation hybrid materials are used [41-44]. By stoichiometric chemical reaction, the metal ions in the solution will have ion exchange with resins and will change into a solid matrix with the same charge. The main advantage of this method is the regeneration of materials; however, only selective metal ions can be removed and it is an expensive method.

\section{Electrochemical Treatment}

In this method, heavy metal ions are removed using electrochemical treatment by three mechanisms: electrocoagulation, electroflotation, and electroxidation [45,46]. It is a low-cost method and extraction of metals can be achieved; however, the operational cost is high because of energy consumption.

\section{Adsorption}

Adsorption is a widely used method to remove heavy metal ions and monolayers of heavy metal ions formed by accumulation on the surface of an adsorbent [47-51]. This is a very simple method, which is effective in metal ion removal, flexible in the design of adsorbents, and unaffected by toxic pollutants. Thus, researchers focused on the development of suitable adsorbents. Polymer-based adsorbents such as such polypyrrole [52], aminated polyacrylonitrile [53], polypyrrole-polyaniline [54], manganese dioxide-loaded biochar [48], metal-organic frameworks [55], natural Jordanian, Zeolite [56], Eucalyptus camaldulensis [57], spherical chitosan-gelatin hydrogel particles [58], graphene oxide embedded hydrogel particles [59], and sodium alginate modified materials [60] are used to remove heavy metal ions from wastewater.

There are many reviews available about the removal of heavy metal ions [61-63] using different adsorbents [52,64-68]. However, only a few reviews discussed the use of hydrogels as adsorbents [69-71]. Thus, here we focus on the recent results of hydrogel adsorbents for the removal of heavy metal ions.

\section{Hydrogels Adsorbents for Heavy Metal Ions}

Hydrogels have a three-dimensional network structure that is capable of retaining water in their network structure. Polar or non-polar monomers are used for the preparation of hydrophilic or hydrophobic hydrogels. Hydrophobic hydrogels are prepared for specific applications. Generally, monomers, initiators, and cross-linkers are involved. Hydrophilic hydrogels are prepared using in situ polymerization of polar monomers. Polymerization techniques such as bulk polymerization, emulsion polymerization, and solution polymerization are used for hydrogel preparation.

Bulk polymerization is a simple technique in which only monomers and initiators are used. The reaction takes place at a high temperature and produces a highly viscous hydrogel because of a high degree of polymerization which causes a high concentration of monomers. This hydrogel will become soft in water [72]. An emulsion or inversesuspension polymerization is oil-in-water emulsion polymerization. Polymerization takes place in the colloidal particles that form in the earlier phase of the process. In this method, monomer, initiator, and cross-linker are used. Surfactants are used for the stabilization of particles which can be easily washed after the preparation of hydrogel particles [58,59]. Solution polymerization is where ionic or neutral monomers are cross-linked. The polymerization is generally initiated by UV-irradiation or by a redox initiator. Solvents are used and are removed after polymerization by immersion of the hydrogels in water, causing a heterogeneous phase separation to take place; thus, the hydrogels are purified [73]. The functional groups in the polymer network will involve ionic or coordination interactions. 
These hydrogels are not dissolved in any solvents [74], are hydrophilic and have a unique three-dimensional structure [75], high swelling degree or ratio [58,59], one or more heteroatoms which are involved in the coordination with heavy metal ions [76,77], and can be reused $[75,78,79]$.

The prepared hydrogels can be characterized using various techniques: crosslinking of polymer can be confirmed by Fourier transform infrared spectroscopy (FTIR) [75-77]; the chemical composition in hydrogels can be confirmed by X-ray photoelectron spectroscopy (XPS) [76]; optical microscope and scanning electron microscope (SEM) measurements will inform about morphology and porosity of hydrogel [76,77]; the strength of hydrogels can be studied using compress strength tests; differential scanning calorimetry (DSC) and thermogravimetry (TG) measurements will report the thermal behavior and stability of hydrogels [80]. The adsorption of heavy metal ions by hydrogels can be quantified using inductively coupled plasma optical emission spectroscopy (ICPOES) measurements [80].

The adsorption capacities or efficiency and percent of removal efficiency are calculated using the following equations: $[58,59,77,81]$

$$
\begin{gathered}
\text { Adsorption Efficiency or Capacity }(\mathrm{Qe})=\frac{\mathrm{A}-\mathrm{B} \times \mathrm{V}}{\mathrm{W}} \\
\text { Removal Efficiency }(\%)=\frac{\mathrm{A}-\mathrm{B}}{\mathrm{A}} \times 100
\end{gathered}
$$

$\mathrm{A}$ and $\mathrm{B}$ are the initial (before the adsorption experiment) and final (after the adsorption experiment) equilibrium concentrations of the heavy metal ions, respectively. $\mathrm{V}$ is the volume of the metal ion used for the adsorption experiment, and $\mathrm{W}$ is the weight of the dried hydrogel used. Using ICPOES, the concentrations (A and B) of heavy metal ions are measured.

The removal of heavy metal ions by hydrogels depends on many factors such as $\mathrm{pH}$, metal ion concentration, the complexing ability of metal ions, ionic radius of metal ions, hydration energy of metal ions, hydrogel structure, swelling degree of hydrogel, uptake time, experimental conditions, and reactive sites available in hydrogels. These factors affect the interaction between hydrogels and heavy metal ions. The adsorption experiments are reported in single and multiple systems. The different hydrogel adsorbents used for the removal of heavy metal ions are tabulated in Tables 1 and 2. Some hydrogels which are used for the adsorption of heavy metal ions are regenerated and used many times.

Figure 3 depicts the removal of heavy metal ions using hydrogel as adsorbents. The polymers will have functional groups such as carbonyl, hydroxyl, carboxylic acid, carboxylate group, and amine groups as shown in Figure 4. Ionic or electrostatic interactions will be involved between the functional groups in polymers and heavy metal ions to make complexation. Furthermore, the removal efficiency of metal ions depends on the affinity of functional groups in polymers towards metal ions. Typically, single-ion system hydrogels are added to a single heavy metal ion solution (Table 1) and multiple system hydrogels are added to a multiple/mixed metal ions solution (Table 2). In both cases, hydrogels adsorbed the heavy metal ions. Thus, in this section, the affinity of polymers or effects of polymers towards the removal efficiency of specific or multiple heavy metal ions are discussed. Hydrogels were prepared by cross-linking 2-acrylamido-2-methylpropane sulfonic acid and 2-methacryloyloxy ethyl dimethyl-3-sulfopropyl ammonium hydroxide monomers using N, N-methylene bisacrylamide. The prepared hydrogels were used for the removal of heavy metal ions $\mathrm{Fe}(\mathrm{III}), \mathrm{Hg}$ (II), and $\mathrm{Cr}$ (III) [70].

The polyacrylic acid hydrogel was used to remove $\mathrm{Cu}(\mathrm{II})$ and $\mathrm{Ni}(\mathrm{II})$ ions from water [77]. 2-acrylamido-2-methyl-1-propane sulfonic acid-based magnetic responsive hydrogels were used to remove heavy metal $\mathrm{Cd}(\mathrm{II}), \mathrm{Co}$ (II), $\mathrm{Fe}(\mathrm{III}), \mathrm{Pb}(\mathrm{II}), \mathrm{Cr}(\mathrm{III}), \mathrm{Ni}(\mathrm{II})$, and $\mathrm{Cu}(\mathrm{II})$ ions. [82] Hydrogels from Brazilian vegetal species were reported as adsorbents for $\mathrm{Mg}(\mathrm{II}), \mathrm{Cr}(\mathrm{III}), \mathrm{Fe}(\mathrm{III})$, and $\mathrm{Zn}(\mathrm{II})$ ions [83]. El-Hag Ali. A. et al. [84] reported the chelating poly(vinyl pyrrolidone/acrylic acid) hydrogels for the removal of $\mathrm{Fe}(\mathrm{III}), \mathrm{Cu}$ (II), and $\mathrm{Mn}$ (II) ions. A magnetic-vinyl pyridine-based hydrogel removed $\mathrm{U}$ and thorium 
metal ion from aqueous environments [85]. Controlled hydrolysis of polyacrylamide resulted in polyacrylamide-polyacrylic acid hydrogel used for the recovery and separation of $\mathrm{Cu}$ (II) and $\mathrm{Cd}(\mathrm{II})$ ions [86]. Laponite/polyvinyl pyrrolidone hydrogel removed $\mathrm{Cu}$ (II) ion efficiently [87].

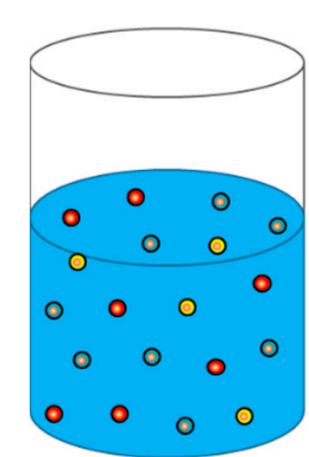

Polluted Water
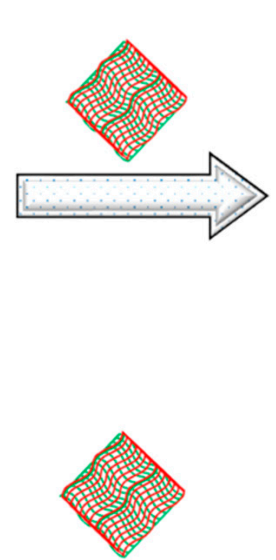

Hydrogel
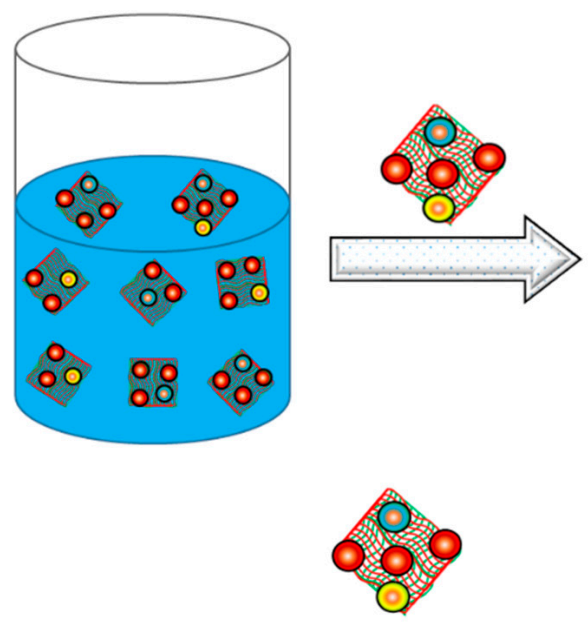

\section{Heavy Metal Ions Adsorbed Hydrogel}

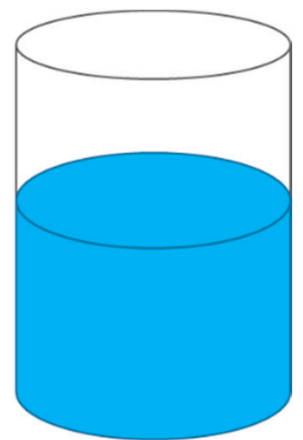

Purified

Water

Figure 3. Schematic representation of the removal of heavy metal ions from polluted water by hydrogel adsorbents.

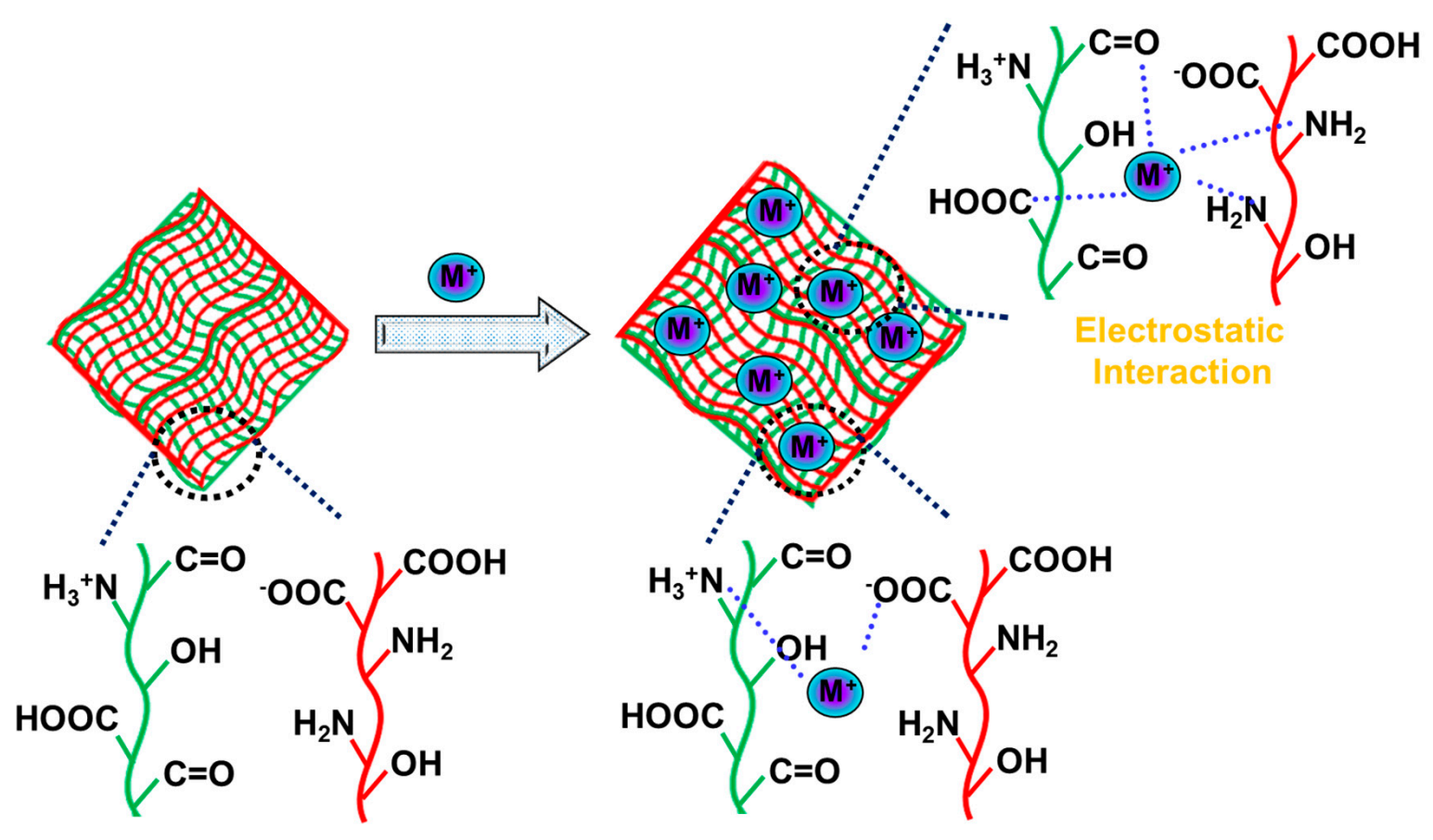

Ionic Interaction

Figure 4. Schematic representation of the mechanism involved during the removal process of heavy metal ions.

Further, ionic monomers are used to prepare hydrogels and the ionic unit promotes the interaction of polymers with heavy metal ions. As $(\mathrm{V})$ was removed efficiently using cationic hydrogel (poly(3-acrylamidopropyl)trimethyl ammonium chloride) with $99.7 \%$ removal efficiency. Sulfonic acid-based hydrogels are used to remove $\mathrm{Cd}(\mathrm{II}), \mathrm{Co}(\mathrm{II}), \mathrm{Cu}(\mathrm{II})$, and $\mathrm{Fe}(\mathrm{III})$ ions [88]. Hydroxyethyl methacrylate-based hydrogels are used for the selective removal of $\mathrm{Fe}(\mathrm{II}), \mathrm{Cu}(\mathrm{II})$, and $\mathrm{Cr}(\mathrm{VI})$ ions in decreasing order [89]. Magnetic propane 
sulfonic acid-based hydrogels showed selective removal capability of toxic metal ions, $\mathrm{Cu}(\mathrm{II}), \mathrm{Cd}(\mathrm{II}), \mathrm{Fe}(\mathrm{II})$, and $\mathrm{Pb}$ (II) ions [90]. After the removal of heavy metal ions, the hydrogels are recovered and reused for many cycles. In the case of polyvinyl alcohol reinforced with multiwalled carbon nanotubes hydrogel used to remove $\mathrm{Pb}$ (II) ion, the prepared hydrogel was reused for four cycles with an adsorption efficiency of more than $80 \%$ after four cycles [91]. Poly(acrylic acid-co-hydroxyethyl methacrylate)-based hydrogels were reported as selective adsorbents for $\mathrm{Pb}$ (II) ions among $\mathrm{Pb}$ (II), $\mathrm{Cu}$ (II), and $\mathrm{Zn}$ (II) ions [76]. Chitosan-based hydrogels, which are prepared by crosslinking of chitosan, polyacrylic acid, and $\mathrm{N}, \mathrm{N}^{\prime}$-methylene bisacrylamide, removed $\mathrm{Cr}(\mathrm{VI})$ ions effectively with $94.72 \%$ [92]. Waste biomass hydrogel of soybean-poly acrylic acid has been used to remove $\mathrm{Cr}$ (III) ion [93]. One review reports the problem of arsenic and the materials used for the removal of arsenic [94]. Molybdate impregnated chitosan beads remove As(V) effectively [95].

Table 1. Adsorption capacity and removal efficiency of heavy metal ions using different adsorbents in single metal ion systems.

\begin{tabular}{|c|c|c|c|c|}
\hline S.No & Hydrogel Adsorbents & Adsorption Capacity (Qe (mg.g $\left.{ }^{-1}\right)$ ) & Removal Efficiency (\%) & Ref. \\
\hline 1. & $\begin{array}{l}\text { Poly(vinylpyrrolidone/acrylic acid) } \\
\text { copolymer hydrogel }\end{array}$ & $\mathrm{Fe}(\mathrm{III})-20, \mathrm{Mn}(\mathrm{II})-1$, and $\mathrm{Cu}(\mathrm{II})-11$ & & [84] \\
\hline 2. & Gelatin-chitosan hydrogel particles & - & $\begin{array}{l}\mathrm{Hg}(\mathrm{II})-98, \mathrm{~Pb}(\mathrm{II})-34, \mathrm{Cd}(\mathrm{II})-20 \\
\text { and } \mathrm{Cr}(\mathrm{III})-16\end{array}$ & [96] \\
\hline 3. & $\begin{array}{l}\text { Chitosan-polyvinylalcohol } \\
\text { hydrogel beads }\end{array}$ & $\mathrm{Pb}(\mathrm{II})-0.9$ & - & [97] \\
\hline 4. & $\begin{array}{l}\text { Spherical chitosan-gelatin } \\
\text { hydrogel particles }\end{array}$ & $\mathrm{Hg}(\mathrm{II})-47.5, \mathrm{~Pb}(\mathrm{II})-7.62, \mathrm{Cd}(\mathrm{II})-0, \mathrm{Cr}(\mathrm{III})-1.5$ & $\begin{array}{l}\mathrm{Hg}(\mathrm{II})-84.7, \mathrm{~Pb}(\mathrm{II})-8.7, \mathrm{Cd}(\mathrm{II})-0, \\
\text { and } \mathrm{Cr}(\mathrm{III})-6.7\end{array}$ & [58] \\
\hline 5. & $\begin{array}{l}\text { Graphene oxide embedded } \\
\text { chitosan-gelatin hydrogel particles }\end{array}$ & $\mathrm{Hg}(\mathrm{II})-54.6, \mathrm{~Pb}(\mathrm{II})-5.4, \mathrm{Cd}(\mathrm{II})-1.67, \mathrm{Cr}(\mathrm{III})-0$ & $\begin{array}{l}\mathrm{Hg}(\mathrm{II})-54.6, \mathrm{~Pb}(\mathrm{II})-7.3, \mathrm{Cd}(\mathrm{II})-1.9 \\
\text { and } \mathrm{Cr}(\mathrm{III})-0\end{array}$ & [59] \\
\hline 6. & Cationic hydrogels & - & As(V)-99.7 & [98] \\
\hline 7. & $\begin{array}{l}\text { Poly(acrlic acid-co-acrylamide) } \\
\text { hydrogels }\end{array}$ & $\mathrm{Cu}(\mathrm{II})-211.7$ & - & [99] \\
\hline 8. & $\begin{array}{l}\text { Poly(acrylamide-co-sodium } \\
\text { methacrylate) hydrogel }\end{array}$ & $\mathrm{Cu}(\mathrm{II})-24.05$ and $\mathrm{Cd}(\mathrm{II})-33.0$ & $\mathrm{Cu}(\mathrm{II})-48$ and $\mathrm{Cd}(\mathrm{II})-66$ & [100] \\
\hline 9. & Soybean hydrogel & $\begin{array}{l}\mathrm{Cd}(\mathrm{II})-1.43 \text { mmol.g } \\
\mathrm{Pb}(\mathrm{II})-2.04 \text { mmol.g } \\
\text {-1 }\end{array}$ & - & [101] \\
\hline 10. & $\begin{array}{l}\text { Terpolymer/montmorillonite } \\
\text { nanocomposite hydrogels }\end{array}$ & $\mathrm{U}(\mathrm{VI})-0.723 \mathrm{~mol} . \mathrm{g}^{-1}$ & - & [102] \\
\hline 11. & $\begin{array}{l}\text { Acrylamide and acrylic } \\
\text { acid hydrogels }\end{array}$ & $\mathrm{U}(\mathrm{VI})-236.6$ & - & [103] \\
\hline 12. & Chitosan hydrogel beads & $\mathrm{Cu}(\mathrm{II})-130$ & - & [104] \\
\hline 13. & Hydrogel-clay nanocomposites & $\begin{array}{c}\mathrm{Cu}(\mathrm{II})-1.07 \mathrm{mmol}^{-1} \mathrm{~g}^{-1} \\
\mathrm{Cd}(\mathrm{II})-1.28 \mathrm{mmol.g}{ }^{-1}, \text { and }^{\mathrm{Pb}} \text { (II) } \\
1.03 \mathrm{mmol.g} \mathrm{g}^{-1}\end{array}$ & - & [105] \\
\hline 14. & Chitosan-based hydrogel & $\mathrm{Ni}(\mathrm{II})-161.8$ & - & [106] \\
\hline 15. & $\begin{array}{l}\text { N-vinyl-2-pyrrolidone-itaconic } \\
\text { acid Hydrogels }\end{array}$ & $\begin{array}{l}\mathrm{Cu}(\mathrm{II})-2.1 \mathrm{mmol}^{-1} \mathrm{~g}^{-1} \text { and } \\
\mathrm{Pb}(\mathrm{II})-0.6 \text { mmol.g }\end{array}$ & - & [107] \\
\hline 16. & Thiourea-based hydrogel & $\mathrm{Pt}(\mathrm{II})-477$ and $\mathrm{Pd}(\mathrm{II})-407$ & $\mathrm{Pt}(\mathrm{II})-96.8$ & [108] \\
\hline 17. & Polyacrylamide-based hydrogel & $\begin{array}{l}\mathrm{Cd}(\mathrm{II})-5.3 \mathrm{mmol} . \mathrm{g}^{-1}, \mathrm{~Pb}(\mathrm{II})-0.63 \mathrm{mmol.g}{ }^{-1} \\
\text { and } \mathrm{Zn}(\mathrm{II})-1.27 \mathrm{mmol.g}\end{array}$ & - & [109] \\
\hline 18. & Graphene oxide composite hydrogel & $\mathrm{Cu}(\mathrm{II})-5.99$ & - & [110] \\
\hline
\end{tabular}


Table 2. Adsorption capacity and removal efficiency of heavy metal ions using different adsorbents in multiple metal ion systems.

\begin{tabular}{|c|c|c|c|c|}
\hline S.No & Hydrogel Adsorbents & $\begin{array}{l}\text { Adsorption Capacity (Qe } \\
\left(\mathrm{mg}^{\left.\left.-g^{-1}\right)\right)}\right.\end{array}$ & Removal Efficiency (\%) & Ref. \\
\hline 1. & Polyacrylic acid hydrogel & $\begin{array}{c}\mathrm{Cd}(\mathrm{II})-132.9, \mathrm{Cr}(\mathrm{VI})-58.1, \\
\mathrm{Fe}(\mathrm{III})-12.4, \mathrm{Mn}(\mathrm{II})-120.4, \\
\mathrm{Ni}(\mathrm{II})-128.8, \mathrm{Ag}(\mathrm{I}) \text { and } \\
\mathrm{Ce}(\mathrm{III})-203.5, \mathrm{Zn}(\mathrm{II})-157.8\end{array}$ & $\begin{array}{l}\mathrm{Cd}(\mathrm{II})-57.1, \mathrm{Cr}(\mathrm{VI})-26.9 \\
\mathrm{Fe}(\mathrm{III})-5.3, \mathrm{Mn}(\mathrm{II})-52.7 \\
\mathrm{Ni}(\mathrm{II})-52.5, \mathrm{Ag}(\mathrm{I})-45.3 \\
\mathrm{Ce}(\mathrm{III})-70, \mathrm{Zn}(\mathrm{II})-58.4\end{array}$ & [79] \\
\hline 2. & $\begin{array}{l}\text { Spherical chitosan-gelatin } \\
\text { hydrogel particles }\end{array}$ & $\begin{array}{c}\mathrm{Hg}(\mathrm{II})-42.7, \mathrm{~Pb}(\mathrm{II})-67.6 \\
\mathrm{Cd}(\mathrm{II})-46.8, \text { and } \mathrm{Cr}(\mathrm{III})-19.2\end{array}$ & $\begin{array}{c}\mathrm{Hg}(\mathrm{II})-93, \mathrm{~Pb}(\mathrm{II})-76.6 \\
\mathrm{Cd}(\mathrm{II})-73.4, \text { and } \mathrm{Cr}(\mathrm{III})-84.2\end{array}$ & [58] \\
\hline 3. & Gelatin-chitosan hydrogel & - & $\begin{array}{l}\mathrm{Hg}(\mathrm{II})-97, \mathrm{~Pb}(\mathrm{II})-12, \mathrm{Cd}(\mathrm{II})-2, \\
\text { and } \mathrm{Cr}(\mathrm{III})-24\end{array}$ & [96] \\
\hline 4. & Cellulose-hydrogel composite & $\mathrm{Pb}(\mathrm{II})-146.19$ and $\mathrm{Zn}(\mathrm{II})-286.67$ & - & [111] \\
\hline 5. & $\begin{array}{l}\text { Graphene oxide embedded } \\
\text { chitosan-gelatin hydrogel particles }\end{array}$ & $\begin{array}{l}\mathrm{Hg}(\mathrm{II})-60.2, \mathrm{~Pb}(\mathrm{II})-60.1 \\
\mathrm{Cd}(\mathrm{II})-39.6, \mathrm{Cr}(\mathrm{III})-14.4\end{array}$ & $\begin{array}{c}\mathrm{Hg}(\mathrm{II})-92.5, \mathrm{~Pb}(\mathrm{II})-78.4 \\
\mathrm{Cd}(\mathrm{II})-74.0, \text { and } \mathrm{Cr}(\mathrm{III})-80.0\end{array}$ & [59] \\
\hline 6. & Sulfonic acid-based hydrogels & $\begin{array}{c}\mathrm{Cd}(\mathrm{II})-0.95, \mathrm{Cu}(\mathrm{II})-0.87 \\
\mathrm{Fe}(\mathrm{III})-0.83, \mathrm{Zn}(\mathrm{II})-1.00 \\
\mathrm{Mn}(\mathrm{II})-0.77, \text { and } \mathrm{Pb}(\mathrm{II})-0.18\end{array}$ & - & [88] \\
\hline 7. & Itaconic-based hydrogels & $\begin{array}{l}\mathrm{Cu}(\mathrm{II})-2.1 \mathrm{mmol} . \mathrm{g}^{-1} \text { and } \\
\mathrm{Pb}(\mathrm{II})-0.6 \mathrm{mmol} . \mathrm{g}^{-1}\end{array}$ & - & [107] \\
\hline 8. & Alginate fibroid hydrogel & $\begin{array}{c}\mathrm{Cu}(\mathrm{II})-316.0, \mathrm{Cd}(\mathrm{II})-232.35 \text {, and } \\
\mathrm{Pb}(\mathrm{II})-465.2\end{array}$ & - & [112] \\
\hline 9. & $\begin{array}{l}\text { poly (vinyl } \\
\text { alcohol)/poly(2-acrylamido-2- } \\
\text { methyl-1-propanesulfonic acid) }\end{array}$ & $\mathrm{Pb}(\mathrm{II})-340$ and $\mathrm{Cd}(\mathrm{II})-155.1$ & $\begin{array}{c}\mathrm{Pb}(\mathrm{II})-88.1, \mathrm{Cd}(\mathrm{II})-91.4, \\
\mathrm{Zn}(\mathrm{II})-70.4, \mathrm{Cu}(\mathrm{II})-77.4, \\
\mathrm{Mn}(\mathrm{II})-42.5, \mathrm{Ni}(\mathrm{II})-45.1, \text { and } \\
\mathrm{Fe}(\mathrm{III})-95.4\end{array}$ & [113] \\
\hline 10. & Guanidine-based hydrogel & $\mathrm{Pb}(\mathrm{II})-27.3$ and $\mathrm{Cd}(\mathrm{II})-28.5$ & - & [114] \\
\hline 11. & $\begin{array}{l}\text { Graphene oxide/alginate } \\
\text { hydrogel membrane }\end{array}$ & $\mathrm{Pb}(\mathrm{II})-327.9$ and $\mathrm{Cr}(\mathrm{III})-118.6$ & - & [115] \\
\hline 12. & Iron crosslinked-chitosan beads & $\mathrm{As}(\mathrm{III})-21.24$ and $\mathrm{As}(\mathrm{V})-27.59$ & - & [116] \\
\hline
\end{tabular}

\section{Conclusions}

Contamination of water bodies with heavy metal ions needs urgent action. Among existing methods such as chemical precipitation, ion exchange, electrochemical treatment, membrane filtration, coagulation, ion flotation, and adsorption; adsorption is a simple, effective, and cost-effective method. The methods used for the preparation of hydrogel adsorbents were presented. The selected research focused on the improvement of adsorbents for the efficient removal of heavy metal ions and the plausible interactions between adsorbents and heavy metal ions is also briefly discussed. This review discussed hydrogels as an effective adsorbent for heavy metal ions. However, a few important aspects should be focused on in the development of hydrogel adsorbents for heavy metal ions. The hydrogels are recycled and reused for many cycles; however, the reported results show a decrease in removal efficiency with cycles. Thus, research should focus on the development of hydrogel adsorbents that maintain removal efficiency. Furthermore, hydrogels mostly remove a specific or few metal ions and complete removal of metal ions is difficult. Hence, additional research should focus on the development of effective adsorbents for the simultaneous and complete removal of multiple heavy metal ions so that adsorbents can be used for the practical application towards the removal of multiple heavy metal ions.

Author Contributions: The review was written with the contributions of all authors. All authors have approved the final version of the manuscript.

Funding: This research received no external funding. 
Institutional Review Board Statement: Not applicable.

Informed Consent Statement: Not applicable.

Data Availability Statement: No supporting data.

Conflicts of Interest: The authors declare no competing financial interest.

\section{References}

1. Maret, W. The Metals in the Biological Periodic System of the Elements: Concepts and Conjectures. Int. J. Mol. Sci. 2016, 17, 66. [CrossRef]

2. Mertz, W. The essential trace elements. Science 1981, 213, 1332-1338. [CrossRef]

3. Arif, N.; Yadav, V.; Singh, S.; Singh, S.; Ahmad, P.; Mishra, R.K.; Sharma, S.; Tripathi, D.K.; Dubey, N.K.; Chauhan, D.K. Influence of High and Low Levels of Plant-Beneficial Heavy Metal Ions on Plant Growth and Development. Front. Environ. Sci. 2016, 4, 69. [CrossRef]

4. Hausen, H. Fluoride toothpaste prevents caries. Evid. Based Dent. 2003, 4, 28. [CrossRef]

5. Vannucci, L.; Fossi, C.; Quattrini, S.; Guasti, L.; Pampaloni, B.; Gronchi, G.; Giusti, F.; Romagnoli, C.; Cianferotti, L.; Marcucci, G.; et al. Calcium Intake in Bone Health: A Focus on Calcium-Rich Mineral Waters. Nutrients 2018, 10, 1930. [CrossRef] [PubMed]

6. Hua, Y.; Clark, S.; Ren, J.; Sreejayan, N. Molecular mechanisms of chromium in alleviating insulin resistance. J. Nutr. Biochem. 2012, 23, 313-319. [CrossRef] [PubMed]

7. Abbaspour, N.; Hurrell, R.; Kelishadi, R. Review on iron and its importance for human health. J. Res. Med. Sci. 2014, 19, 164-174. [PubMed]

8. Roohani, N.; Hurrell, R.; Kelishadi, R.; Schulin, R. Zinc and its importance for human health: An integrative review. J. Res. Med. Sci. 2013, 18, 144-157. [PubMed]

9. Mertz, W. Human Requirements: Basic and Optimal. Ann. N. Y. Acad. Sci. 1972, 199, 191-201. [CrossRef]

10. Bansal, S.L.; Asthana, S. Biologically Essential and Non-Essential Elements Causing Toxicity in Environment. J. Environ. Anal. Toxicol. 2018, 8, 1-5. [CrossRef]

11. Chronopoulos, J.; Haidouti, C.; Chronopoulou-Sereli, A.; Massas, I. Variations in plant and soil lead and cadmium content in urban parks in Athens, Greece. Sci. Total Environ. 1997, 196, 91-98. [CrossRef]

12. Maret, W.; Sandstead, H.H. Zinc requirements and the risks and benefits of zinc supplementation. J. Trace Elements Med. Biol. 2006, 20, 3-18. [CrossRef] [PubMed]

13. Plum, L.M.; Rink, L.; Haase, H. The Essential Toxin: Impact of Zinc on Human Health. Int. J. Environ. Res. Public Health 2010, 7, 1342-1365. [CrossRef]

14. Uluozlu, O.D.; Tuzen, M.; Soylak, M. Speciation and separation of $\mathrm{Cr}(\mathrm{VI})$ and $\mathrm{Cr}(\mathrm{III})$ using coprecipitation with Ni2+/2-Nitroso1-naphthol-4-sulfonic acid and determination by FAAS in water and food samples. Food Chem. Toxicol. 2009, 47, 2601-2605. [CrossRef] [PubMed]

15. Richtera, L.; Nguyen, H.V.; Hynek, D.; Kudr, J.; Adam, V. Electrochemical speciation analysis for simultaneous determination of $\mathrm{Cr}$ (iii) and $\mathrm{Cr}$ (vi) using an activated glassy carbon electrode. Analyst 2016, 141, 5577-5585. [CrossRef]

16. Fytianos, K. Speciation Analysis of Heavy Metals in Natural Waters: A Review. J. AOAC Int. 2001, 84, 1763-1769. [CrossRef] [PubMed]

17. Amrane, C.; Bouhidel, K.E. Analysis and speciation of heavy metals in the water, sediments, and drinking water plant sludge of a deep and sulfate-rich Algerian reservoir. Environ. Monit. Assess. 2019, 191, 73. [CrossRef] [PubMed]

18. Shamsipur, M.; Fattahi, N.; Assadi, Y.; Sadeghi, M.; Sharafi, K. Speciation of As(III) and As(V) in water samples by graphite furnace atomic absorption spectrometry after solid phase extraction combined with dispersive liquid-liquid microextraction based on the solidification of floating organic drop. Talanta 2014, 130, 26-32. [CrossRef]

19. Liang, P.; Peng, L.; Yan, P. Speciation of $\mathrm{As}(\mathrm{III})$ and $\mathrm{As}(\mathrm{V})$ in water samples by dispersive liquid-liquid microextraction separation and determination by graphite furnace atomic absorption spectrometry. Microchim. Acta 2009, 166, 47-52. [CrossRef]

20. Smichowski, P.; Marrero, J.; Ledesma, A.; Polla, G.; Batistoni, D.A. Speciation of As(iii) and As(v) in aqueous solutions using baker's yeast and hydride generation inductively coupled plasma atomic emission spectrometric determination. J. Anal. At. Spectrom. 2000, 15, 1493-1497. [CrossRef]

21. Dvoynenko, O.; Lo, S.-L.; Chen, Y.-J.; Chen, G.W.; Tsai, H.-M.; Wang, Y.-L.; Wang, J.-K. Speciation Analysis of Cr(VI) and Cr(III) in Water with Surface-Enhanced Raman Spectroscopy. ACS Omega 2021, 6, 2052-2059. [CrossRef] [PubMed]

22. Singh, R.; Gautam, N.; Mishra, A.; Gupta, R. Heavy metals and living systems: An overview. Indian J. Pharmacol. 2011, 43, 246-253. [CrossRef] [PubMed]

23. Meshitsuka, S.; Ishizawa, M.; Nose, T. Uptake and toxic effects of heavy metal ions: Interactions among cadmium, copper and zinc in cultured cells. Experientia 1987, 43, 151-156. [CrossRef] [PubMed]

24. Shen, X.; Lee, K.; König, R. Effects of heavy metal ions on resting and antigen-activated CD4+ T cells. Toxicology 2001, 169, 67-80. [CrossRef]

25. Obasi, P.N.; Akudinobi, B.B. Potential health risk and levels of heavy metals in water resources of lead-zinc mining communities of Abakaliki, southeast Nigeria. Appl. Water Sci. 2020, 10, 184. [CrossRef] 
26. Fu, Z.; Xi, S. The effects of heavy metals on human metabolism. Toxicol. Mech. Methods 2020, 30, 167-176. [CrossRef] [PubMed]

27. Gautam, R.K.; Sharma, S.K.; Mahiya, S.; Chattopadhyaya, M.C. Chapter 1 Contamination of Heavy Metals in Aquatic Media: Transport, Toxicity and Technologies for Remediation. In Heavy Metals in Water: Presence, Removal and Safety; Royal Society of Chemistry: London, UK, 2014; pp. 1-24.

28. Jaishankar, M.; Tseten, T.; Anbalagan, N.; Mathew, B.B.; Beeregowda, K.N. Toxicity, mechanism and health effects of some heavy metals. Interdiscip. Toxicol. 2014, 7, 60-72. [CrossRef]

29. Pohl, A. Removal of Heavy Metal Ions from Water and Wastewaters by Sulfur-Containing Precipitation Agents. Water Air Soil Pollut. 2020, 231, 503. [CrossRef]

30. Zhang, Y.; Duan, X. Chemical precipitation of heavy metals from wastewater by using the synthetical magnesium hydroxy carbonate. Water Sci. Technol. 2020, 81, 1130-1136. [CrossRef]

31. Chen, Q.; Luo, Z.; Hills, C.; Xue, G.; Tyrer, M. Precipitation of heavy metals from wastewater using simulated flue gas: Sequent additions of fly ash, lime and carbon dioxide. Water Res. 2009, 43, 2605-2614. [CrossRef]

32. Hargreaves, A.J.; Vale, P.; Whelan, J.; Alibardi, L.; Constantino, C.; Dotro, G.; Cartmell, E.; Campo, P. Coagulation-flocculation process with metal salts, synthetic polymers and biopolymers for the removal of trace metals $(\mathrm{Cu}, \mathrm{Pb}, \mathrm{Ni}, \mathrm{Zn})$ from municipal wastewater. Clean Technol. Environ. Policy 2018, 20, 393-402. [CrossRef]

33. Amuda, O.S.; Amoo, I.; Ipinmoroti, K.; Ajayi, O. Coagulation/flocculation process in the removal of trace metals present in industrial wastewater. J. Appl. Sci. Environ. Manag. 2006, 10, 159-162. [CrossRef]

34. Teh, C.Y.; Budiman, P.M.; Shak, K.P.Y.; Wu, T.Y. Recent Advancement of Coagulation-Flocculation and Its Application in Wastewater Treatment. Ind. Eng. Chem. Res. 2016, 55, 4363-4389. [CrossRef]

35. Blöcher, C.; Dorda, J.; Mavrov, V.; Chmiel, H.; Lazaridis, N.; Matis, K. Hybrid flotation-membrane filtration process for the removal of heavy metal ions from wastewater. Water Res. 2003, 37, 4018-4026. [CrossRef]

36. Cao, D.-Q.; Wang, X.; Wang, Q.-H.; Fang, X.-M.; Jin, J.-Y.; Hao, X.-D.; Iritani, E.; Katagiri, N. Removal of heavy metal ions by ultrafiltration with recovery of extracellular polymer substances from excess sludge. J. Membr. Sci. 2020, 606, 118103. [CrossRef]

37. Khulbe, K.C.; Matsuura, T. Removal of heavy metals and pollutants by membrane adsorption techniques. Appl. Water Sci. 2018, 8, 19. [CrossRef]

38. Taseidifar, M.; Makavipour, F.; Pashley, R.M.; Rahman, A.F.M.M. Removal of heavy metal ions from water using ion flotation. Environ. Technol. Innov. 2017, 8, 182-190. [CrossRef]

39. Polat, H.; Erdogan, D. Heavy metal removal from waste waters by ion flotation. J. Hazard. Mater. 2007, 148, 267-273. [CrossRef]

40. Chang, L.; Cao, Y.; Fan, G.; Li, C.; Peng, W. A review of the applications of ion floatation: Wastewater treatment, mineral beneficiation and hydrometallurgy. RSC Adv. 2019, 9, 20226-20239. [CrossRef]

41. Zewail, T.; Yousef, N. Kinetic study of heavy metal ions removal by ion exchange in batch conical air spouted bed. Alex. Eng. J. 2015, 54, 83-90. [CrossRef]

42. Dabrowski, A.; Hubicki, Z.; Podkoscielny, P.; Robens, E. Selective removal of the heavy metal ions from waters and industrial wastewaters by ion-exchange method. Chemosphere 2004, 56, 91-106. [CrossRef] [PubMed]

43. Bashir, A.; Malik, L.A.; Ahad, S.; Manzoor, T.; Bhat, M.A.; Dar, G.N.; Pandith, A.H. Removal of heavy metal ions from aqueous system by ion-exchange and biosorption methods. Environ. Chem. Lett. 2019, 17, 729-754. [CrossRef]

44. Vaaramaa, K.; Lehto, J. Removal of metals and anions from drinking water by ion exchange. Desalination 2003, 155, 157-170. [CrossRef]

45. Tran, T.-K.; Leu, H.-J.; Chiu, K.-F.; Lin, C.-Y. Electrochemical Treatment of Heavy Metal-containing Wastewater with the Removal of COD and Heavy Metal Ions. J. Chin. Chem. Soc. 2017, 64, 493-502. [CrossRef]

46. Tran, T.-K.; Chiu, K.-F.; Lin, C.-Y.; Leu, H.-J. Electrochemical treatment of wastewater: Selectivity of the heavy metals removal process. Int. J. Hydrog. Energy 2017, 42, 27741-27748. [CrossRef]

47. Zhao, G.; Huang, X.; Tang, Z.; Huang, Q.; Niu, F.; Wang, X.-K. Polymer-based nanocomposites for heavy metal ions removal from aqueous solution: A review. Polym. Chem. 2018, 9, 3562-3582. [CrossRef]

48. Zhang, H.; Xu, F.; Xue, J.; Chen, S.; Wang, J.; Yang, Y. Enhanced removal of heavy metal ions from aqueous solution using manganese dioxide-loaded biochar: Behavior and mechanism. Sci. Rep. 2020, 10, 6067. [CrossRef]

49. Vo, T.S.; Hossain, M.M.; Jeong, H.M.; Kim, K. Heavy metal removal applications using adsorptive membranes. Nano Converg. 2020, 7, 36. [CrossRef]

50. Al-Senani, G.M.; Al-Fawzan, F.F. Adsorption study of heavy metal ions from aqueous solution by nanoparticle of wild herbs Egypt. J. Aquat. Res. 2018, 44, 187-194. [CrossRef]

51. Salam, O.E.A.; Reiad, N.A.; ElShafei, M.M. A study of the removal characteristics of heavy metals from wastewater by low-cost adsorbents. J. Adv. Res. 2011, 2, 297-303. [CrossRef]

52. Mahmud, H.N.M.E.; Huq, A.K.O.; Yahya, R.B. The removal of heavy metal ions from wastewater/aqueous solution using polypyrrole-based adsorbents: A review. RSC Adv. 2016, 6, 14778-14791. [CrossRef]

53. Deng, S.; Bai, R. Removal of trivalent and hexavalent chromium with aminated polyacrylonitrile fibers: Performance and mechanisms. Water Res. 2004, 38, 2424-2432. [CrossRef] [PubMed]

54. Bhaumik, M.; Maity, A.; Srinivasu, V.; Onyango, M.S. Removal of hexavalent chromium from aqueous solution using polypyrrolepolyaniline nanofibers. Chem. Eng. J. 2012, 181-182, 323-333. [CrossRef] 
55. Chen, Y.; Bai, X.; Ye, Z. Recent Progress in Heavy Metal Ion Decontamination Based on Metal-Organic Frameworks. Nanomaterials 2020, 10, 1481. [CrossRef] [PubMed]

56. Baker, H.M.; Massadeh, A.M.; Younes, H.A. Natural Jordanian zeolite: Removal of heavy metal ions from water samples using column and batch methods. Environ. Monit. Assess. 2009, 157, 319-330. [CrossRef]

57. Gebretsadik, H.; Gebrekidan, A.; Demlie, L. Removal of heavy metals from aqueous solutions using Eucalyptus Camaldulensis: An alternate low cost adsorbent. Cogent Chem. 2020, 6, 1720892. [CrossRef]

58. Perumal, S.; Atchudan, R.; Yoon, D.H.; Joo, J.; Cheong, I.W. Spherical Chitosan/Gelatin Hydrogel Particles for Removal of Multiple Heavy Metal Ions from Wastewater. Ind. Eng. Chem. Res. 2019, 58, 9900-9907. [CrossRef]

59. Perumal, S.; Atchudan, R.; Yoon, D.H.; Joo, J.; Cheong, I.W. Graphene oxide-embedded chitosan/gelatin hydrogel particles for the adsorptions of multiple heavy metal ions. J. Mater. Sci. 2020, 55, 9354-9363. [CrossRef]

60. Zhao, Y.; Zhan, L.; Xue, Z.; Yusef, K.K.; Hu, H.; Wu, M. Adsorption of Cu (II) and Cd (II) from Wastewater by Sodium Alginate Modified Materials. J. Chem. 2020, 2020, 5496712. [CrossRef]

61. Arora, R. Adsorption of Heavy Metals-A Review. Mater. Today Proc. 2019, 18, 4745-4750. [CrossRef]

62. Fu, F.; Wang, Q. Removal of heavy metal ions from wastewaters: A review. J. Environ. Manag. 2011, 92, 407-418. [CrossRef] [PubMed]

63. Hong, Y.; Liao, W.; Yan, Z.; Bai, Y.; Feng, C.; Xu, Z.; Xu, D. Progress in the Research of the Toxicity Effect Mechanisms of Heavy Metals on Freshwater Organisms and Their Water Quality Criteria in China. J. Chem. 2020, 2020, 9010348. [CrossRef]

64. Lata, S.; Singh, P.K.; Samadder, S.R. Regeneration of adsorbents and recovery of heavy metals: A review. Int. J. Environ. Sci. Technol. 2015, 12, 1461-1478. [CrossRef]

65. Ngah, W.W.; Hanafiah, M.A.K.M. Removal of heavy metal ions from wastewater by chemically modified plant wastes as adsorbents: A review. Bioresour. Technol. 2008, 99, 3935-3948. [CrossRef]

66. Wołowiec, M.; Komorowska-Kaufman, M.; Pruss, A.; Rzepa, G.; Bajda, T. Removal of Heavy Metals and Metalloids from Water Using Drinking Water Treatment Residuals as Adsorbents: A Review. Minerals 2019, 9, 487. [CrossRef]

67. Prabhu, P.P.; Prabhu, B. A Review on Removal of Heavy Metal Ions from Waste Water using Natural/Modified Bentonite. MATEC Web Conf. 2018, 144, 02021. [CrossRef]

68. Renu; Agarwal, M.; Singh, K. Heavy metal removal from wastewater using various adsorbents: A review. J. Water Reuse Desalination 2016, 7, 387-419. [CrossRef]

69. Muya, F.N.; Sunday, C.E.; Baker, P.; Iwuoha, E. Environmental remediation of heavy metal ions from aqueous solution through hydrogel adsorption: A critical review. Water Sci. Technol. 2016, 73, 983-992. [CrossRef]

70. Chowdhury, N.; Solaiman; Roy, C.K.; Firoz, S.H.; Foyez, T.; Bin Imran, A. Role of Ionic Moieties in Hydrogel Networks to Remove Heavy Metal Ions from Water. ACS Omega 2021, 6, 836-844. [CrossRef]

71. Shalla, A.H.; Yaseen, Z.; Bhat, M.A.; Rangreez, T.A.; Maswal, M. Recent review for removal of metal ions by hydrogels. Sep. Sci. Technol. 2019, 54, 89-100. [CrossRef]

72. Jafari, M.; Najafi, G.R.; Sharif, M.A.; Elyasi, Z. Superabsorbent polymer composites derived from polyacrylic acid: Design and synthesis, characterization, and swelling capacities. Polym. Polym. Compos. 2020, 26, 1-7. [CrossRef]

73. Thakur, S.; Arotiba, O. Synthesis, characterization and adsorption studies of an acrylic acid-grafted sodium alginate-based TiO2 hydrogel nanocomposite. Adsorpt. Sci. Technol. 2018, 36, 458-477. [CrossRef]

74. Wang, Q.; Xie, X.; Zhang, X.; Zhang, J.; Wang, A. Preparation and swelling properties of pH-sensitive composite hydrogel beads based on chitosan-g-poly (acrylic acid)/vermiculite and sodium alginate for diclofenac controlled release. Int. J. Biol. Macromol. 2010, 46, 356-362. [CrossRef]

75. Zheng, Y.; Wang, A. Removal of heavy metals using polyvinyl alcohol semi-IPN poly(acrylic acid)/tourmaline composite optimized with response surface methodology. Chem. Eng. J. 2010, 162, 186-193. [CrossRef]

76. Chen, J.; Jiang, X.; Yin, D.; Zhang, W. Preparation of a Hydrogel-Based Adsorbent for Metal Ions through High Internal Phase Emulsion Polymerization. ACS Omega 2020, 5, 19920-19927. [CrossRef] [PubMed]

77. Mishra, A.; Nath, A.; Pande, P.P.; Shankar, R. Treatment of gray wastewater and heavy metal removal from aqueous medium using hydrogels based on novel crosslinkers. J. Appl. Polym. Sci. 2021, 138, 50242. [CrossRef]

78. Van Tran, V.; Park, D.; Lee, Y.-C. Hydrogel applications for adsorption of contaminants in water and wastewater treatment. Environ. Sci. Pollut. Res. 2018, 25, 24569-24599. [CrossRef]

79. Lv, Q.; Hu, X.; Zhang, X.; Huang, L.; Liu, Z.; Sun, G. Highly efficient removal of trace metal ions by using poly(acrylic acid) hydrogel adsorbent. Mater. Des. 2019, 181, 107934. [CrossRef]

80. Anceschi, A.; Caldera, F.; Bertasa, M.; Cecone, C.; Trotta, F.; Bracco, P.; Zanetti, M.; Malandrino, M.; Mallon, P.E.; Scalarone, D. New Poly ( $\beta$-Cyclodextrin)/Poly(Vinyl Alcohol) Electrospun Sub-Micrometric Fibers and Their Potential Application for Wastewater Treatments. Nanomaterials 2020, 10, 482. [CrossRef]

81. Wahlström, N.; Steinhagen, S.; Toth, G.; Pavia, H.; Edlund, U. Ulvan dialdehyde-gelatin hydrogels for removal of heavy metals and methylene blue from aqueous solution. Carbohydr. Polym. 2020, 249, 116841. [CrossRef]

82. Ozay, O.; Ekici, S.; Baran, Y.; Aktaş, N.; Sahiner, N. Removal of toxic metal ions with magnetic hydrogels. Water Res. 2009, 43, 4403-4411. [CrossRef] [PubMed]

83. Carvalho, H.W.P.; Batista, A.P.L.; Hammer, P.; Luz, G.H.P.; Ramalho, T.C. Removal of metal ions from aqueous solution by chelating polymeric hydrogel. Environ. Chem. Lett. 2010, 8, 343-348. [CrossRef] 
84. Ali, A.E.-H.; Shawky, H.; El Rehim, H.A.; Hegazy, E. Synthesis and characterization of PVP/AAc copolymer hydrogel and its applications in the removal of heavy metals from aqueous solution. Eur. Polym. J. 2003, 39, 2337-2344. [CrossRef]

85. Ozay, O.; Ekici, S.; Aktas, N.; Sahiner, N. P(4-vinyl pyridine) hydrogel use for the removal of UO22+ and Th4+ from aqueous environments. J. Environ. Manag. 2011, 92, 3121-3129. [CrossRef] [PubMed]

86. Li, W.; Zhao, H.; Teasdale, P.; John, R.; Zhang, S. Synthesis and characterisation of a polyacrylamide-polyacrylic acid copolymer hydrogel for environmental analysis of $\mathrm{Cu}$ and Cd. React. Funct. Polym. 2002, 52, 31-41. [CrossRef]

87. Wang, Y.M.; Shang, D.J.; Niu, Z.W. Removal of Heavy Metals by Poly(Vinyl Pyrrolidone)/Laponite Nanocomposite Hydrogels. Adv. Mater. Res. 2013, 631-632, 291-297. [CrossRef]

88. Atta, A.; Ismail, H.S.; Mohamed, H.M.; Mohamed, Z.M. Acrylonitrile/acrylamidoxime/2-acrylamido-2- methylpropane sulfonic acid-based hydrogels: Synthesis, characterization and their application in the removal of heavy metals. J. Appl. Polym. Sci. 2011, 122, 999-1011. [CrossRef]

89. Chauhan, G.S.; Chauhan, S.; Sen, U.; Garg, D. Synthesis and characterization of acrylamide and 2-hydroxyethyl methacrylate hydrogels for use in metal ion uptake studies. Desalination 2009, 243, 95-108. [CrossRef]

90. Ozay, O.; Ekici, S.; Baran, Y.; Kubilay, S.; Aktaş, N.; Sahiner, N. Utilization of magnetic hydrogels in the separation of toxic metal ions from aqueous environments. Desalination 2010, 260, 57-64. [CrossRef]

91. Zulfiqar, M.; Lee, S.Y.; Mafize, A.A.; Kahar, N.A.M.A.; Johari, K.; Rabat, N.E. Efficient Removal of Pb(II) from Aqueous Solutions by Using Oil Palm Bio-Waste/MWCNTs Reinforced PVA Hydrogel Composites: Kinetic, Isotherm and Thermodynamic Modeling. Polymers 2020, 12, 430. [CrossRef]

92. Vilela, P.B.; Dalalibera, A.; Duminelli, E.C.; Becegato, V.A.; Paulino, A.T. Adsorption and removal of chromium (VI) contained in aqueous solutions using a chitosan-based hydrogel. Environ. Sci. Pollut. Res. 2019, 26, 28481-28489. [CrossRef]

93. Zhang, M.; Song, L.; Jiang, H.; Li, S.; Shao, Y.; Yang, J.; Li, J. Biomass based hydrogel as an adsorbent for the fast removal of heavy metal ions from aqueous solutions. J. Mater. Chem. A 2017, 5, 3434-3446. [CrossRef]

94. Pathan, S.; Bose, S. Arsenic Removal Using “Green” Renewable Feedstock-Based Hydrogels: Current and Future Perspectives. ACS Omega 2018, 3, 5910-5917. [CrossRef] [PubMed]

95. Dambies, L.; Guibal, E.; Roze, A. Arsenic(V) sorption on molybdate-impregnated chitosan beads. Colloids Surfaces A: Physicochem. Eng. Asp. 2000, 170, 19-31. [CrossRef]

96. Lone, S.; Yoon, D.H.; Lee, H.M.; Cheong, I.W. Gelatin-chitosan hydrogel particles for efficient removal of $\mathrm{Hg}$ (ii) from wastewater. Environ. Sci. Water Res. Technol. 2019, 5, 83-90. [CrossRef]

97. Jin, L.; Bai, R. Mechanisms of Lead Adsorption on Chitosan/PVA Hydrogel Beads. Langmuir 2002, 18, 9765-9770. [CrossRef]

98. Barakat, M.; Sahiner, N. Cationic hydrogels for toxic arsenate removal from aqueous environment. J. Environ. Manag. 2008, 88, 955-961. [CrossRef]

99. Morán-Quiroz, J.L.; Orozco-Guareño, E.; Manríquez, R.; Carbajal-Arízaga, G.G.; de la Cruz, W.; Gomez-Salazar, S. Polymeric hydrogels obtained using a redox initiator: Application in $\mathrm{Cu}(\mathrm{II})$ ions removal from aqueous solutions. J. Appl. Polym. Sci. 2014, 131, 39933. [CrossRef]

100. Milosavljević, N.; Debeljković, A.; Krušić, M.K.; Milašinović, N.; Üzüm, Ö.B.; Karadağ, E. Application of poly(acrlymide-co-sodium methacrylate) hydrogels in copper and cadmium removal from aqueous solution. Environ. Prog. Sustain. Energy 2014, 33, 824-834. [CrossRef]

101. Zhang, M.; Yin, Q.; Ji, X.; Wang, F.; Gao, X.; Zhao, M. High and fast adsorption of Cd(II) and Pb(II) ions from aqueous solutions by a waste biomass based hydrogel. Sci. Rep. 2020, 10, 3285. [CrossRef]

102. Ortaboy, S.; Acar, E.T.; Atun, G.; Emik, S.; İyim, T.B.; Güçlü, G.; Özgümüş, S. Performance of acrylic monomer based terpolymer/montmorillonite nanocomposite hydrogels for U(VI) removal from aqueous solutions. Chem. Eng. Res. Des. 2013, 91, 670-680. [CrossRef]

103. Raj, L.; Chauhan, G.S. Uranyl ions uptake on poly(AAc/AAm)-cl-N,N-MBAAm hydrogel. Polym. Bull. 2010, 64, 363-374. [CrossRef]

104. Yan, H.; Dai, J.; Yang, Z.; Yang, H.; Cheng, R. Enhanced and selective adsorption of copper(II) ions on surface carboxymethylated chitosan hydrogel beads. Chem. Eng. J. 2011, 174, 586-594. [CrossRef]

105. Kaşgöz, H.; Durmus, A.; Kaşgöz, A. Enhanced swelling and adsorption properties of AAm-AMPSNa/clay hydrogel nanocomposites for heavy metal ion removal. Polym. Adv. Technol. 2008, 19, 213-220. [CrossRef]

106. Zheng, Y.; Huang, D.; Wang, A. Chitosan-g-poly(acrylic acid) hydrogel with crosslinked polymeric networks for Ni2+ recovery. Anal. Chim. Acta 2011, 687, 193-200. [CrossRef]

107. Evren, M.; Acar, I.; Güçlü, K.; Güçlü, G. Removal of $\mathrm{Cu2+and} \mathrm{Pb2+ions} \mathrm{byN-vinyl} \mathrm{2-pyrrolidone/itaconic} \mathrm{acid} \mathrm{hydrogels} \mathrm{from}$ aqueous solutions. Can. J. Chem. Eng. 2014, 92, 52-59. [CrossRef]

108. Döker, S.; Malc1, S.; Doğan, M.; Salih, B. New poly(N-(hydroxymethyl)methacrylamide-1-allyl-2-thiourea) hydrogels prepared by radiation-induced polymerisation: Selective adsorption, recovery and pre-concentration of $\mathrm{Pt}(\mathrm{II})$ and $\mathrm{Pd}(\mathrm{II})$. Anal. Chim. Acta 2005, 553, 73-82. [CrossRef]

109. Sharaf, M.A.; Arida, H.A.; Sayed, S.A.; Younis, A.A.; Farag, A.B. Separation and preconcentration of some heavy-metal ions using new chelating polymeric hydrogels. J. Appl. Polym. Sci. 2009, 113, 1335-1344. [CrossRef]

110. Choi, J.-W.; Kim, H.J.; Ryu, H.; Oh, S.; Choi, S.-J. Three-dimensional double-network hydrogels of graphene oxide, alginate, and polyacrylonitrile for copper removal from aqueous solution. Environ. Eng. Res. 2020, 25, 924-929. [CrossRef] 
111. Astrini, N.; Anah, L.; Haryadi, H.R. Adsorption of Heavy Metal Ion from Aqueous Solution by Using Cellulose Based Hydrogel Composite. Macromol. Symp. 2015, 353, 191-197. [CrossRef]

112. Kong, C.; Zhao, X.; Li, Y.; Yang, S.; Chen, Y.M.; Yang, Z. Ion-Induced Synthesis of Alginate Fibroid Hydrogel for Heavy Metal Ions Removal. Front. Chem. 2020, 7, 905. [CrossRef] [PubMed]

113. Ma, J.; Zhang, Y.; Tang, Y.; Wei, Y.; Liu, Y.; Liu, C. Efficient removal of heavy metals from melting effluent using multifunctional hydrogel adsorbents. Water Sci. Technol. 2018, 78, 982-990. [CrossRef] [PubMed]

114. Yetimoğlu, E.K.; Fırlak, M.; Kahraman, M.V.; Deniz, S. Removal of Pb2+ and Cd2+ ions from aqueous solutions using guanidine modified hydrogels. Polym. Adv. Technol. 2011, 22, 612-619. [CrossRef]

115. Bai, C.; Wang, L.; Zhu, Z. Adsorption of $\mathrm{Cr}(\mathrm{III})$ and $\mathrm{Pb}(\mathrm{II})$ by graphene oxide/alginate hydrogel membrane: Characterization, adsorption kinetics, isotherm and thermodynamics studies. Int. J. Biol. Macromol. 2020, 147, 898-910. [CrossRef]

116. Neto, J.D.O.M.; Bellato, C.R.; Milagres, J.L.; Pessoa, K.D.; De Alvarenga, E.S. Preparation and evaluation of chitosan beads immobilized with Iron(III) for the removal of As(III) and As(V) from water. J. Braz. Chem. Soc. 2013, 24, 121-132. [CrossRef] 